\title{
Gold-dppm-Arylazoimidazole Complexes: Synthesis, Spectra, and Redox Study
}

\author{
Prithwiraj Byabartta1,2 \\ ${ }^{1}$ Departmento de Quimica Inorganica, Instituto de Ciencia de Materiales de Aragon, Universidad de Zaragoza-CSIC, \\ 50009 Zaragoza, Spain \\ ${ }^{2}$ Haldia Institute of Technology, Hatiberia, Haldia, Midnapur 721657, India
}

Correspondence should be addressed to Prithwiraj Byabartta, pribatta@rediffmail.com

Received 31 July 2009; Accepted 23 September 2009

Copyright ( 2010 Prithwiraj Byabartta. This is an open access article distributed under the Creative Commons Attribution License, which permits unrestricted use, distribution, and reproduction in any medium, provided the original work is properly cited.

\begin{abstract}
$[\mathrm{Ag}($ tht $)(\mathrm{OTf})]$-assisted reaction produces $\left[\mathrm{Au}^{\mathrm{III}}(\mathrm{dppm})(\mathrm{tht})_{2}\right]\left(\mathrm{OSO}_{2} \mathrm{CF}_{3}\right)_{2}$, reacts with RaaiR' in dichloromethane medium followed by ligand addition, and leads to $\left[\mathrm{Au}^{\mathrm{III}}(\mathrm{dppm})\left(\mathrm{RaaiR}^{\prime}\right)\right](\mathrm{OTf})_{2}\left(\mathrm{RaaiR}^{\prime}=p-\mathrm{R}-\mathrm{C}_{6} \mathrm{H}_{4}-\mathrm{N}=\mathrm{N}-\mathrm{C}_{3} \mathrm{H}_{2}-\mathrm{NN}-1-\mathrm{R}^{\prime},(1-3)\right.$, abbreviated as $\mathrm{N}, \mathrm{N}^{\prime}$-chelator, where $\mathrm{N}$ (imidazole) and $\mathrm{N}($ azo $)$ represent $\mathrm{N}$ and $\mathrm{N}^{\prime}$, resp.; $\mathrm{R}=\mathrm{H}(a), \mathrm{Me}(b), \mathrm{Cl}(c)$ and $\mathrm{R}^{\prime}=\mathrm{Me}$ (1), $\mathrm{CH}_{2} \mathrm{CH}_{3}(2), \mathrm{CH}_{2} \mathrm{Ph}(3)$, dppm is diphenylphosphinomethane, $\mathrm{OSO}_{2} \mathrm{CF}_{3}$ is the triflate anion, and tht is tetrahydrothiophen). Ir spectra of the complexes show $-\mathrm{C}=\mathrm{N}-$ and $-\mathrm{N}=\mathrm{N}-$ stretching near at 1590 and $1370 \mathrm{~cm}^{-1}$ and near at $1100,755,695,545$, and $505 \mathrm{~cm}^{-1}$ due to the presence of dppm. The ${ }^{1} \mathrm{H}$ NMR spectral measurements suggest that methylene, $-\mathrm{CH}_{2}-$, in $\mathrm{RaaiEt}_{\text {gives a }}$ complex $\mathrm{AB}$ type multiplet while in $\mathrm{RaaiCH}_{2} \mathrm{Ph}$ it shows $\mathrm{AB}$ type quartets. Electrochemistry assigns ligand reduction.
\end{abstract}

\section{Introduction}

The biochemistry of gold with D-penicillamine, gluthadione, thiomalic acid, 2,3-dimercaptopropanol, [1,2], and albumin has been studied. The reactivity of gold occurs through the thiolate function of these biological molecules and leads to the formation of gold(I) thiolates, also called chrysotherapy agents. Other types of gold complexes used in medicinal chemistry are gold(I) mono- or bis-phosphines. They can bind to DNA via the guanine and cytosine bases $[3,4]$ and act as antitumor agents against L1210 leukemia and M5076 reticulum cell sarcoma. In 1972, Sutton synthesized a gold complex with a thiolate and a phosphine ligand: the 2, 3, 4, 6-tetra- $O$-acetyl-1-thioD-pyranosato-S-(triethylphosphine) gold(I) compound also known by the trade name Auranofin. It became one of the most promising gold complexes in medicinal chemistry, with a great potency against rheumatoid arthritis and cancer cells such as P388 leukemia and B16. A small number of scattered observations in the early structural chemistry of gold(I) complexes [5] have grown into a wealth of reports on related phenomena in the last two decades, which finally provided a clear pattern of the conditions under which direct interactions between closedshell gold(I) centers can contribute significantly to the stability of molecular and multidimensional structures. The underlying "aurophilic" bonding has been analyzed in theoretical studies $[6,7]$. Syntheses of hetero-tris-chelates, $\left[\mathrm{Ru}(\mathrm{bpy})_{n}\left(\mathrm{RaaiR}^{\prime}\right)_{3-n}\right]\left(\mathrm{ClO}_{4}\right)_{2}\left[\right.$ bpy $=2,2^{\prime}$-bipyridine; $n=$ $1, n=2)$ containing labile reaction centres are reported from Professor Sinha's laboratory. Professor A. Chakravorty has unfolded this ligands rhenium chemistry. But the gold chemistry with multinuclear NMR spectroscopy of this ligand system is totally unexplored. In this paper, I examine the reaction of RaaiR' on gold(III) dppm derivatives and the products are isolated, $\left[\mathrm{Au}(\mathrm{dppm})\left(\mathrm{RaaiR}^{\prime}\right)\right](\mathrm{OTf})_{3}\left(\mathrm{RaaiR}^{\prime}\right.$ $=p-\mathrm{R}-\mathrm{C}_{6} \mathrm{H}_{4}-\mathrm{N}=\mathrm{N}-\mathrm{C}_{3} \mathrm{H}_{2}-\mathrm{NN}-1-\mathrm{R}^{\prime},(1-3)$, abbreviated as $\mathrm{N}, \mathrm{N}^{\prime}$-chelator, where $\mathrm{N}$ (imidazole) and $\mathrm{N}($ azo $)$ represent $\mathrm{N}$ and $\mathrm{N}^{\prime}$, resp.; $\mathrm{R}=\mathrm{H}(a), \mathrm{Me}(b), \mathrm{Cl}(c)$ and $\mathrm{R}^{\prime}=$ $\mathrm{Me}$ (1), $\mathrm{CH}_{2} \mathrm{CH}_{3}(2), \mathrm{CH}_{2} \mathrm{Ph}$ (3), dppm is diphenylphosphinomethane, $\mathrm{OSO}_{2} \mathrm{CF}_{3}$ is the triflate anion, and tht is tetrahydrothiophen). The complexes are well charecterised by i.r., ${ }^{1} \mathrm{H}$ n.m.r., ${ }^{13} \mathrm{C}$ nmr, ${ }^{1} \mathrm{H}-{ }^{1} \mathrm{H}$ COSY nmr, ${ }^{1} \mathrm{H}-{ }^{13} \mathrm{C}$ HMQC, and mass spectrometry. 
$\left[\mathrm{Au}(\mathrm{dppm}) \mathrm{Cl}_{2}\right]+2[\mathrm{Ag}(\mathrm{tht})(\mathrm{OTf})] \longrightarrow\left[\mathrm{Au}(\mathrm{dppm})(\text { tht })_{2}\right](\mathrm{OTf})_{2}+2 \mathrm{AgCl}$

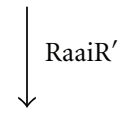

$\left[\mathrm{Au}(\mathrm{dppm})\left(\mathrm{RaaiR}^{\prime}\right)\right](\mathrm{OTf})_{2}$

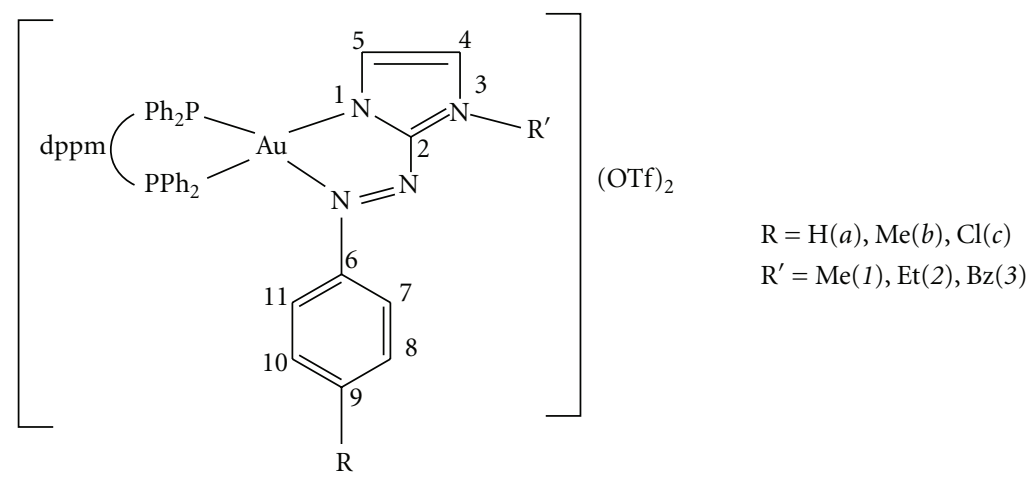

SCHeme 1

\section{Results and Discussion}

The complexes, $\left[\mathrm{Au}^{\mathrm{III}}(\mathrm{dppm})\left(\mathrm{RaaiR}^{\prime}\right)\right](\mathrm{OTf})_{2}\left(\right.$ RaaiR $^{\prime}=$ $p-\mathrm{R}-\mathrm{C}_{6} \mathrm{H}_{4}-\mathrm{N}=\mathrm{N}-\mathrm{C}_{3} \mathrm{H}_{2}-\mathrm{NN}-1-\mathrm{R}^{\prime}$, (1-3), abbreviated as $\mathrm{N}, \mathrm{N}^{\prime}$-chelator, where $\mathrm{N}$ (imidazole) and $\mathrm{N}($ azo $)$ represent $\mathrm{N}$ and $\mathrm{N}^{\prime}$, resp.; $\mathrm{R}=\mathrm{H}(a), \mathrm{Me}(b), \mathrm{Cl}(c)$ and $\mathrm{R}^{\prime}=$ Me (1), $\mathrm{CH}_{2} \mathrm{CH}_{3}$ (2), $\mathrm{CH}_{2} \mathrm{Ph}$ (3), dppm is diphenylphosphinomethane, $\mathrm{OSO}_{2} \mathrm{CF}_{3}$ is the triflate anion, and that is tetrahydrothiophen), were prepared by removing tht from $\left[\mathrm{Au}^{\mathrm{III}}(\mathrm{dppm})(\mathrm{tht})_{2}\right]\left(\mathrm{OSO}_{2} \mathrm{CF}_{3}\right)_{2}$, with RaaiR' under stirring at $343-353 \mathrm{~K}$ in dichloromethane solution in good yield $(75 \%-80 \%)$. The synthetic routes are shown in Scheme 1. The composition of the complexes is supported by microanalytical results. The red orange complexes are soluble in common organic solvents, namely. acetone, acetonitrile, chloroform, and dichloromethane but insoluble in $\mathrm{H}_{2} \mathrm{O}$, methanol, and ethanol. In MeCN, the complexes, (1-3) behave as $1: 2$ electrolytes $\left(\Lambda_{\mathrm{M}}=60-90 \Omega^{-1} \mathrm{~cm}^{-1} \mathrm{~mol}^{-1}\right)$.

I.r. spectra of the complexes show a $1: 1$ correspondence to the spectra of the bromo analogue, except for the appearance of intense stretching at $1365-1370$ and $1570-1580 \mathrm{~cm}^{-1}$ with concomitant loss of $v(\mathrm{Au}-\mathrm{Cl})$ at $320-340 \mathrm{~cm}^{-1}$. They are assigned to $\nu(\mathrm{N}=\mathrm{N})$ and $\nu(\mathrm{C}=\mathrm{N})$ appear at $1365-$ 1380 and $1570-1600 \mathrm{~cm}^{-1}$, respectively (Figure 1 ). Other important frequencies are $v(\mathrm{dppm})$ at $1110-1120,1200$ $1210,1250-1260,750-760,695-700$, and $500-510 \mathrm{~cm}^{-1}$ along with weak bands at $545-550 \mathrm{~cm}^{-1}$. Phosphorous n.m.r., ${ }^{31} \mathrm{P}\left\{{ }^{1} \mathrm{H}\right\} \mathrm{nmr}$, gives a concrete idea on the nature of complexes and is very much informative of the present series of complexes. Due to the presence of azo-imine function, which is pi acidic in nature, stabilises the gold (III) oxidation state giving the value of 36.3 . Fluorine n.m.r., ${ }^{19} \mathrm{~F}\{\mathrm{H}\} \mathrm{NMR}$, of the present series of complexes shows a sharp peak at -78 for the presence of triflate ion. The ${ }^{1} \mathrm{H}$ n.m.r. spectra of (1-3) complexes were unambiguously assigned (Figures 1 and 2) on comparing with parent complex and the free ligand (RaaiR'). The proton movement upon substitution
$(9-\mathrm{R})$ is corroborated with the electromeric effect of R. The aryl protons $(7-\mathrm{H}-11-\mathrm{H})$ of (7-9) are downfield shifted by $0.1-0.7 \mathrm{ppm}$ as compared to those of the parent derivatives. They are affected by substitution; $8-$ and $10-\mathrm{H}$ are severely perturbed due to changes in the electronic properties of the substituents in the $\mathrm{C}(9)$-position. Imidazole 4- and 5$\mathrm{H}$ appear as doublet at the lower-frequency side of the spectra $(7.0-7.2 \mathrm{ppm}$ for $4-\mathrm{H} ; 6.9-7.1 \mathrm{ppm}$ for $5-\mathrm{H})$. The aryl protons $7-\left(7^{\prime}-\right)$ and $11-\left(11^{\prime}-\right) \mathrm{H}$ resonate asymmetrically indicating a magnetically anisotropic environment even in the solution phase. The 1- $\mathrm{R}^{\prime}$ [ $\left.\mathrm{R}^{\prime}=\mathrm{Me}, \mathrm{CH}_{2} \mathrm{CH}_{3}, \mathrm{CH}_{2}(\mathrm{Ph})\right]$ exhibits usual spin-spin interaction. 1-Me appears as a singlet at $2.0 \mathrm{ppm}$ for $[\mathrm{Au}(\mathrm{dppm})(\mathrm{RaaiMe})]^{2+}$; the methylene protons $1-\mathrm{CH}_{2}-\left(\mathrm{CH}_{3}\right)$ show $\mathrm{AB}$ type quartet (ca. 4.4, $\left.4.6 \mathrm{ppm}\right)$ and $\left(1-\mathrm{CH}_{2}\right) \mathrm{CH}_{3}$ gives a triplet at $1.5 \mathrm{ppm}(7.0-8.0 \mathrm{~Hz})$ for $\left[\mathrm{Au}(\mathrm{dppm})\left(\mathrm{RaaiCH}_{2} \mathrm{CH}_{3}\right)\right]^{2+}$. 1- $\mathrm{CH}_{2}(\mathrm{Ph})$ protons appear at $\mathrm{AB}$ type quartets (ca. 5.5, 5.7 ppm) with geminal coupling constant avgerage $8.8 \mathrm{~Hz}$ in $\left[\mathrm{Au}(\mathrm{dppm})\left(\mathrm{RaaiCH}_{2} \mathrm{Ph}\right)\right]^{2+}$ (Scheme 2).

The ${ }^{13} \mathrm{C}(\mathrm{H}) \mathrm{NMR}$ spectrum provides direct information about the carbon skeleton of the molecule. Assignment of different resonant peaks to respective carbon atoms is done on nine complexes and the data are given on experimental section (Figures 1 and 2). The carbon atom is adjacent to the $\mathrm{PPh}_{3}$ molecule in the complex resonance at a lower field resulting in the conjugative effect of the phenyl ring with more electronegative pi-conjugate system. The methyl carbon atom of the imidazole ring resonates at $30 \mathrm{ppm}$, reasonably comparing to the other carbon atoms resonance. In the COSY spectrum, absence of any off-diagonal peaks extending from $\delta=14.1 \mathrm{ppm}$ and $9.5 \mathrm{ppm}$ confirms their assignment of no proton on $\mathrm{N}(1)$ and $\mathrm{N}(3)$, respectively. However, extending horizontal and vertical lines from $\delta=$ $8.3 \mathrm{ppm}[\mathrm{C}(8) \mathrm{H}]$ and $8.6 \mathrm{ppm}[\mathrm{C}(10) \mathrm{H}]$ encounter cross peaks at $\delta=7.1 \mathrm{ppm}$ and $7.2 \mathrm{ppm}$, where the $\mathrm{C}(7) \mathrm{H}$ and $\mathrm{C}(11) \mathrm{H}$ resonances are merged into multiplets along with the phenyl ring proton resonances. The ${ }^{1} \mathrm{H}-{ }^{13} \mathrm{C}$ heteronuclear 
<smiles>[R]c1ccc(N2N=C3N([R])C=CN3[Y]2([H])c2ccccc2)cc1</smiles>

Isomer A

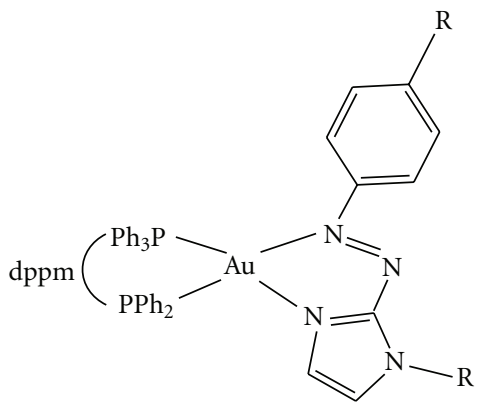

Isomer B

SCHEME 2

multiple-quantum coherence (HMQC) spectrum provides information regarding the interaction between the protons and the carbon atoms to which they are directly attached. The peaks observed at $\delta=134,131,135 \mathrm{ppm}$, and $137 \mathrm{ppm}$ assign them to the $\mathrm{C}(9), \mathrm{C}(8), \mathrm{C}(7), \mathrm{C}(11)$, and $\mathrm{C}(10)$ carbon atoms, respectively, due to their interaction with $\mathrm{H}$ resonance at $\delta=7.4,7.5,7.8,7.80 \mathrm{ppm}$, and $7.3 \mathrm{ppm}$. The electrochemical properties of the complexes were examined cyclic voltammetrically at a glassy carbon-working electrode in $\mathrm{MeCN}$ and the potentials are referred to SCE. The voltammogram shows the ligand reductions at the negative to SCE. In the potential range +2.0 to $-2.0 \mathrm{~V}$ at the scan rate $50 \mathrm{mVs}^{-1}$ two redox couples are observed prominent and all are at the negative side of the voltammogram. One electron nature of the redox process is supported by the $i_{\mathrm{pa}} / i_{\mathrm{pc}}$ ratio $\left(i_{\mathrm{pa}}=\right.$ anodic peak current and $i_{\mathrm{pc}}=$ cathodic peak current $)$ which varies from -0.60 to -0.79 and from -0.90 to -1.05 . Two redox couples at negative to SCE are due to reductions of ligand.

\section{Conclusion}

This work describes the isolation of a novel series of Gold(III) azo-imine complexes, $\left[\mathrm{Au}^{\mathrm{III}}(\mathrm{dppm})\left(\mathrm{RaaiR}^{\prime}\right)\right](\mathrm{OTf})_{2}$, and their spectral and elemental characterisation. ${ }^{1} \mathrm{H}$ NMR study suggests quartet splitting of ethyl substitution. ${ }^{31} \mathrm{P}\left\{{ }^{1} \mathrm{H}\right\} \mathrm{NMR}$ is very much informative and they show that the sharp signals at $36.13 \mathrm{ppm}{ }^{13} \mathrm{C}\left({ }^{1} \mathrm{H}\right) \mathrm{NMR}$ study suggests molecular skeleton. ${ }^{1} \mathrm{H}-{ }^{1} \mathrm{H}$ COSY spectrum as well as contour peaks in the ${ }^{1} \mathrm{H}-{ }^{13} \mathrm{C}$ HMQC spectrum assigns them to the carbon hydrogen atoms interaction. Electrochemistry assigns ligand reduction part rather than metal oxidation.

\section{Experimental}

Published methods were used to prepare RaaiR', $\left[\mathrm{Au}^{\mathrm{III}}(\mathrm{dppm})(\mathrm{Cl})_{2}\right]$. All other chemicals and organic solvents used for preparative work were of reagent grade (SRL, Sigma Alhrich). The purification of MeCN used as solvent and other solvents was done following literature method. Microanalytical data $(\mathrm{C}, \mathrm{H}, \mathrm{N})$ were collected using a Perkin Elmer $2400 \mathrm{CHN}$ instrument. I.r. spectra were obtained using a JASCO 420 spectrophotometer (using $\mathrm{KBr}$ disks, $4000-200 \mathrm{~cm}^{-1}$ ). The ${ }^{1} \mathrm{H} \mathrm{nmr}$ spectra in $\mathrm{CDCl}_{3}$ were obtained on a Bruker $500 \mathrm{MHz}$ FT n.m.r spectrometer using $\mathrm{SiMe}_{4}$ as internal reference, $\mathrm{CFCl}_{3}$ (external ${ }^{19} \mathrm{~F}$ ). Solution electrical conductivities were measured using a Systronics 304 conductivity meter with solute concentration $\sim 10^{-3} \mathrm{M}$ in acetonitrile. Mass spectra were recorded on VG Autospec ESI-mass spectrometry. Electrochemical work was carried out using an EG \& G PARC Versastat computer-controlled 250 electrochemical system. All experiments were performed under an $\mathrm{N}_{2}$ atmosphere at $298 \mathrm{~K}$ using a Pt-disk milli working electrode at a scan rate of $50 \mathrm{mVs}^{-1}$. All results were referenced to a saturated calomel electrode (SCE).

\subsection{Preparation of the Complexes [A $\left.u^{I I I}(\mathrm{dppm})(\mathrm{HaaiEt})\right]$} $(\mathrm{OTf})_{3}, \mathbf{2 b}$. To a dichloromethane slight yellow colour solution $\left(15 \mathrm{~cm}^{3}\right)$ of $\left[\mathrm{Au}^{\mathrm{III}}(\mathrm{dppm}) \mathrm{Cl}_{2}\right](0.665 \mathrm{~g}, 0.10 \mathrm{mmol})$ $[\mathrm{Ag}($ tht $)(\mathrm{OTf})]$ was added $(1 \quad: \quad 2)$ to produce $\left[\mathrm{Au}^{\mathrm{III}}(\mathrm{dppm})(\mathrm{tht})_{2}\right]\left(\mathrm{OSO}_{2} \mathrm{CF}_{3}\right)_{2} \quad(0.945 \mathrm{~g}, \quad 0.20 \mathrm{mmol})$ into this, yellow dichloromethane solution of 1-ethyl-2(p-tolylazo)imidazole was added slowly, dropwise, and the mixture was stirred at $343-353 \mathrm{~K}$ for 12 hours, where, respectively, added the other ligands, HeaaiMe $(0.0186 \mathrm{~g}$, $0.1 \mathrm{mmol}, 1 \mathrm{a})$, MeaaiMe (0.020 g, $0.1 \mathrm{mmol}, 1 \mathbf{b})$, ClaaiMe $(0.0220 \mathrm{~g}, 0.1 \mathrm{mmol}, 1 \mathrm{c})$, HaaiEt $(0.020 \mathrm{~g}, 0.1 \mathrm{mmol}$, 2a), MeaaiEt $(0.0214 \mathrm{~g}, 0.1 \mathrm{mmol}, 2 \mathbf{b})$, ClaaiEt $(0.0235 \mathrm{~g}$, $0.1 \mathrm{mmol}, 2 \mathrm{c})$, HaaiBz $(0.0262 \mathrm{~g}, 0.1 \mathrm{mmol}, 3 \mathrm{a})$, MeaaiBz $(0.0276 \mathrm{~g}, 0.1 \mathrm{mmol}, 3 \mathbf{b})$, and ClaaiBz $(0.0297 \mathrm{~g}, 0.1 \mathrm{mmol}$, $3 c)$. The orange solution that resulted was concentrated $\left(4 \mathrm{~cm}^{3}\right)$ and kept in a refrigerator overnight (1 hour). The addition of hexane to the above red solution gives precipitate which was collected by filtration, washed thoroughly with hexane to remove excess ligand, and then dried in vacuo over pump overnight. The yield was $0.088 \mathrm{~g}(80 \%)$. All other complexes were prepared similarly as stated above.

Analysis for $\left[\mathrm{Au}^{\mathrm{III}}(\mathrm{dppm})(\mathrm{HaaiMe})\right](\mathrm{OTf})_{2}, \mathbf{1 a}$, Found, $\mathrm{C}$, 54.83, H, 4.16, N, 7.36, Calcd. For $\left[\mathrm{C}_{35} \mathrm{H}_{32} \mathrm{~N}_{4} \mathrm{P}_{2} \mathrm{Au}\right]\left(\mathrm{OSO}_{2}\right.$ $\left.\mathrm{CF}_{3}\right)_{2}, \mathrm{C}, 54.8, \mathrm{H}, 4.2, \mathrm{~N}, 7.4 ; \mathrm{IR} \nu(\mathrm{N}=\mathrm{N}) 1370 \nu(\mathrm{C}=\mathrm{N}) 1590$ $v(\mathrm{dppm}) 1100,750,690,550,505 ;{ }^{31} \mathrm{P}\left\{{ }^{1} \mathrm{H}\right\} \mathrm{NMR}, \mathrm{ppm}$, 36.13; ${ }^{1} \mathrm{H}$ NMR, ppm, 8.2(d, $\left.\mathrm{H}(7,11), J=8 \mathrm{~Hz}\right), 8.02(\mathrm{~d}$, 


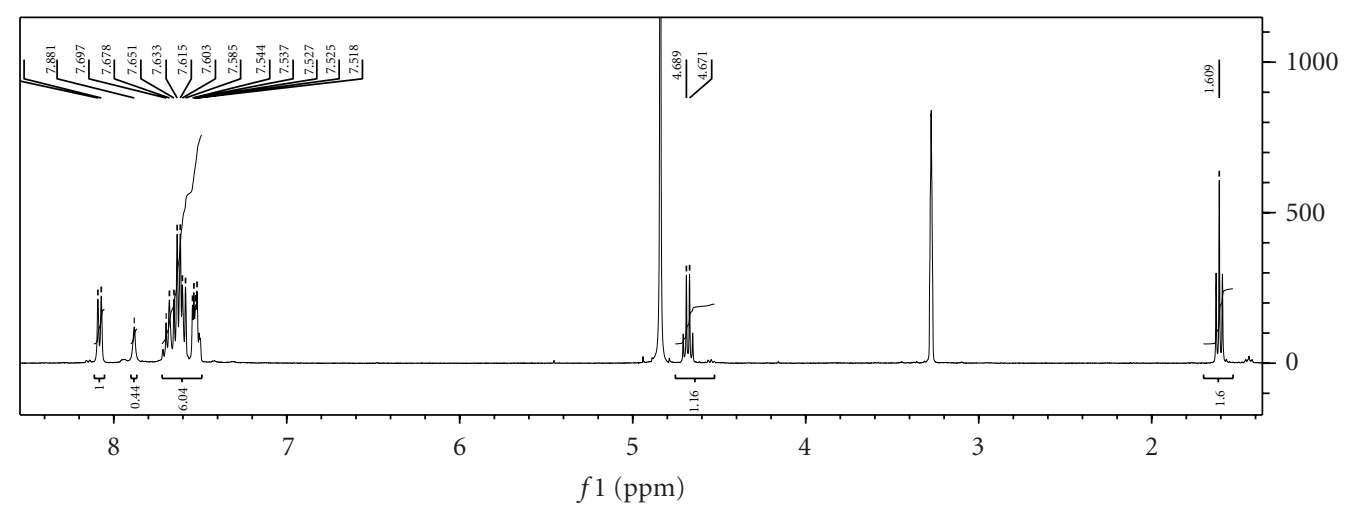

(a)

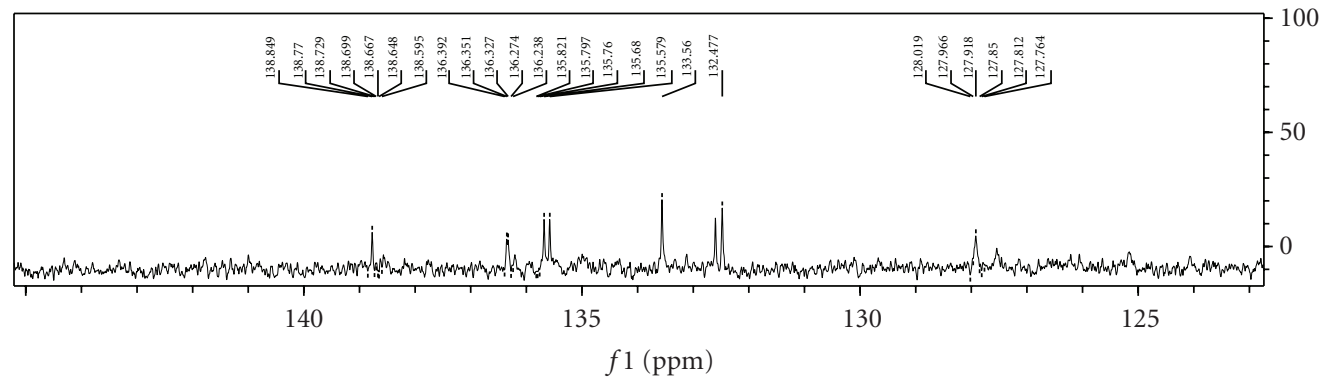

(b)

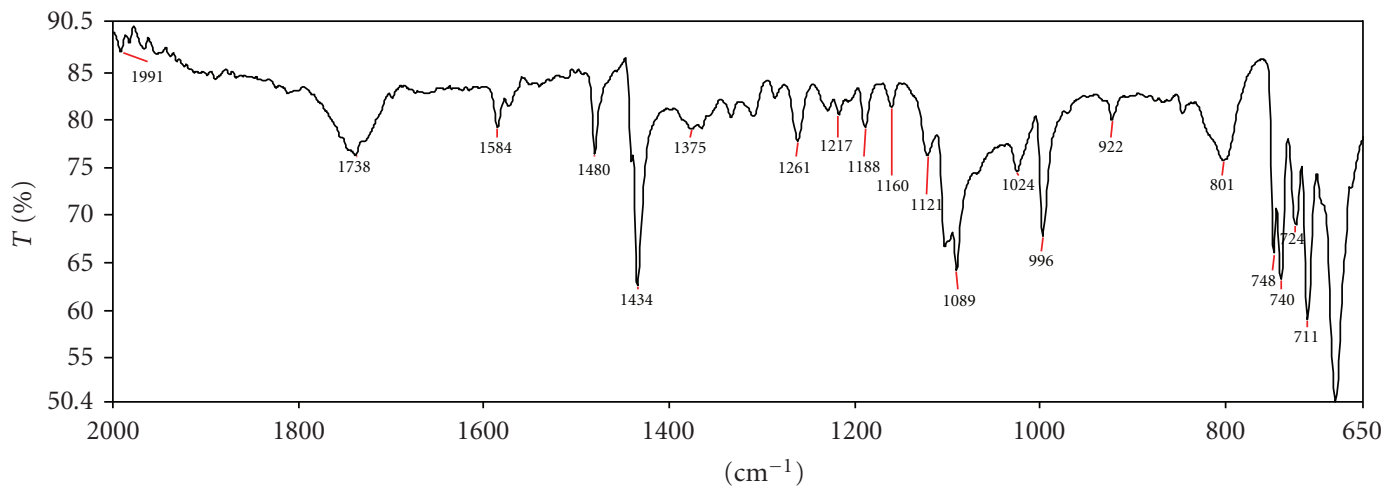

(c)

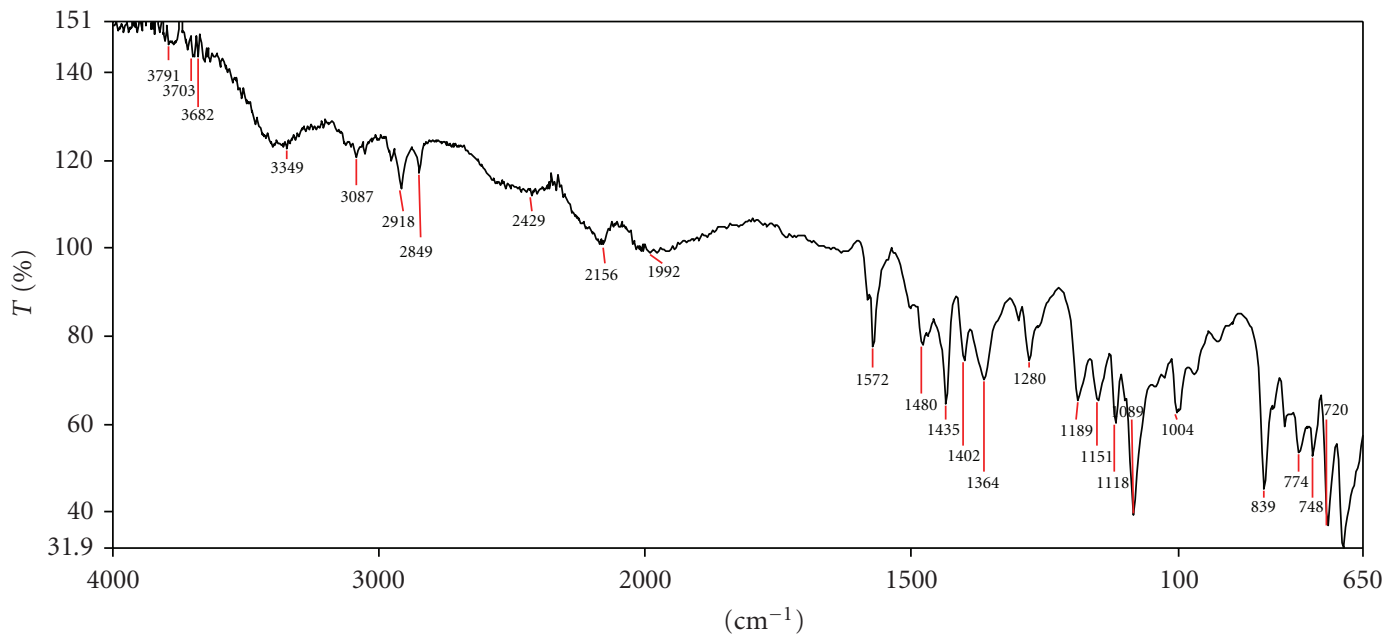

(d)

Figure 1: From above, H NMR, ${ }^{13} \mathrm{C}(\mathrm{H}) \mathrm{NMR}$ of complex $\mathbf{2} \mathbf{a}$ and below, IR spectra of complex $\mathbf{2 a}$ and $\mathbf{2} \mathbf{b}$. 


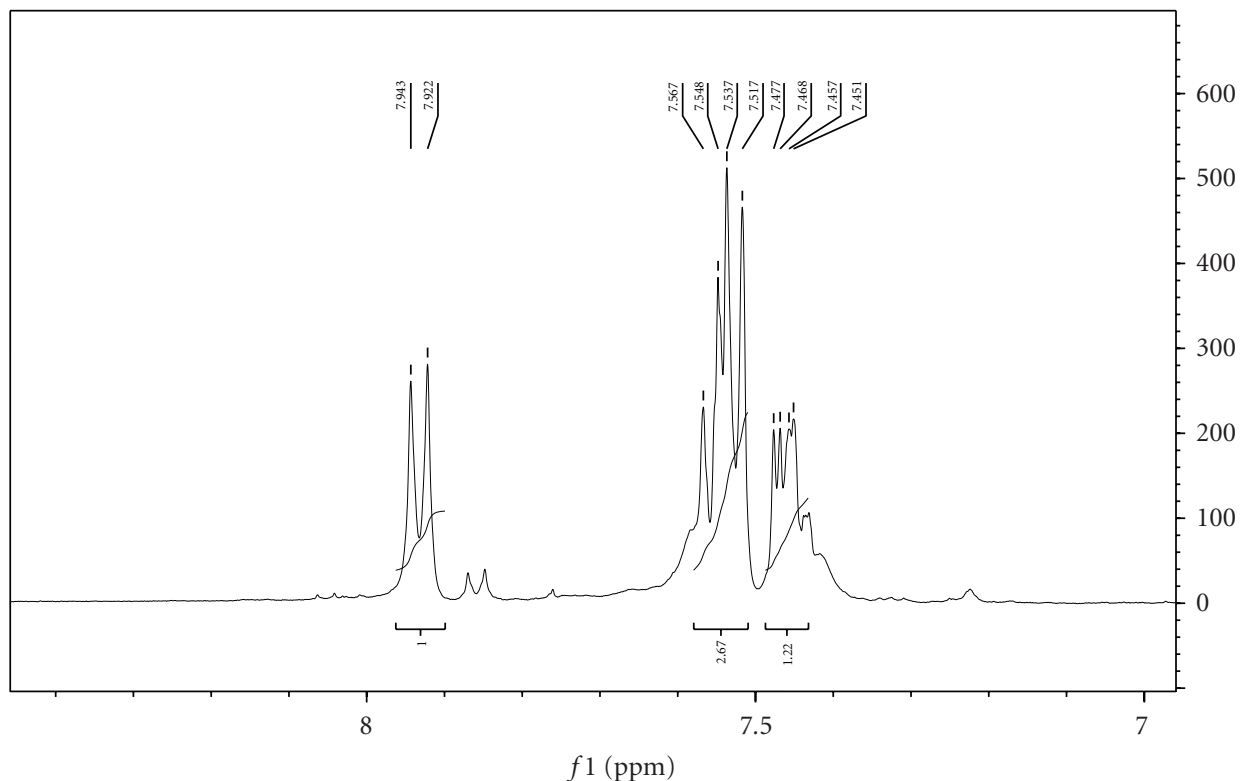

(a)

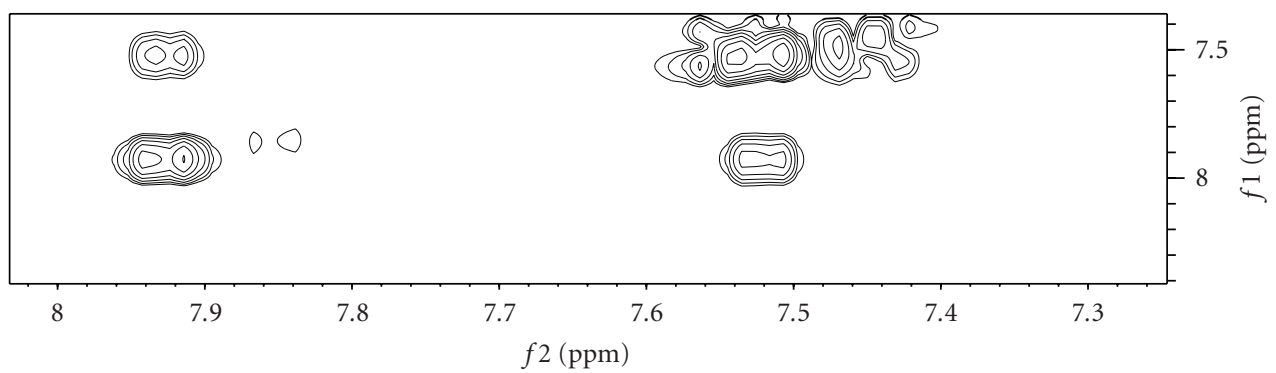

(b)

Figure 2: H NMR of complex $2 \mathrm{c}$ and H H COSY NMR of complex $2 \mathrm{c}$ and its extended portion.

$\mathrm{H}(8,10), J=6.5 \mathrm{~Hz}), 7.26(\mathrm{~d}, \mathrm{H}(4), J=6 \mathrm{~Hz}), 7.34(\mathrm{~d}$, $\mathrm{H}(5), J=5 \mathrm{~Hz}), 7.1-7.2(\mathrm{~m}, \mathrm{dppm}) ;{ }^{19} \mathrm{~F}\left\{{ }^{1} \mathrm{H}\right\} \mathrm{NMR}$, ppm, -78.02 (OTf), ${ }^{13} \mathrm{C}\left\{{ }^{1} \mathrm{H}\right\}$ NMR, ppm, 129.1, 129.3$130.4(\mathrm{dppm}, \quad 18 \mathrm{C}), \quad 134.5(\mathrm{C} 2), \quad 124(\mathrm{C} 4), \quad 125(\mathrm{C} 5)$, 125.3(C7,11), 129.2(C8,10), 134(C6), 42(Me Gr.); ESIMS, 767(M-OTf); Analysis for $\left[\mathrm{Au}^{\mathrm{III}}(\mathrm{dppm})(\right.$ MeaaiMe) $](\mathrm{OTf})_{2}$, 1b, Found, $\mathrm{C}, 55.3, \mathrm{H}, 4.6, \mathrm{~N}, 7.3$, Calcd. For $\left[\mathrm{C}_{36} \mathrm{H}_{34} \mathrm{~N}_{4} \mathrm{P}_{2} \mathrm{Au}\right]\left(\mathrm{OSO}_{2} \mathrm{CF}_{3}\right)_{2}, \mathrm{C}, 55.8, \mathrm{H}, 4.5, \mathrm{~N}, 7.2$; IR $v(\mathrm{~N}=\mathrm{N}) 1370 v(\mathrm{C}=\mathrm{N}) 1590 \nu(\mathrm{dppm}) 1100,750,690$, 550, 505; ${ }^{31} \mathrm{P}\left\{{ }^{1} \mathrm{H}\right\} \mathrm{NMR}, \mathrm{ppm}, 36.1 ;{ }^{1} \mathrm{H}$ NMR, ppm, 8.0(d, $\mathrm{H}(7,11), J=8 \mathrm{~Hz}), 8.12(\mathrm{~d}, \mathrm{H}(8,10), J=6 \mathrm{~Hz}), 1.9(\mathrm{~s}$, $\left.\mathrm{H}\left(\mathrm{CH}_{3}\right),\right), 7.2(\mathrm{~d}, \mathrm{H}(4), J=6 \mathrm{~Hz}), 7.44(\mathrm{~d}, \mathrm{H}(5), J=7 \mathrm{~Hz})$, 7.01-7.2(m, dppm); ${ }^{19} \mathrm{~F}\left\{{ }^{1} \mathrm{H}\right\} \mathrm{NMR}, \mathrm{ppm},-78.02(\mathrm{OTf})$, ${ }^{13} \mathrm{C} \quad\left\{{ }^{1} \mathrm{H}\right\} \mathrm{NMR}, \quad$ ppm, $129.1, \quad 129.3-130.4$ (dppm, 18C), 134.5(C2), 124(C4), 125(C5), 125.3(C7,11), 129.2(C8,10), 134(C6), ESIMS, 781(M-OTf); Analysis for $\left[\mathrm{Au}^{\mathrm{III}}(\mathrm{dppm})(\right.$ ClaaiMe $\left.)\right](\mathrm{OTf})_{2}, \mathbf{1 c}$, Found, $\mathrm{C}, 52.43, \mathrm{H}$, 3.86, N, 6.96, Calcd. For $\left[\mathrm{C}_{35} \mathrm{H}_{31} \mathrm{~N}_{4} \mathrm{P}_{2} \mathrm{AuCl}\right]\left(\mathrm{OSO}_{2} \mathrm{CF}_{3}\right)_{2}$, C, 52.8, H, 3.82, N, 7.0; IR $\nu(\mathrm{N}=\mathrm{N}) 1370 \nu(\mathrm{C}=\mathrm{N}) 1590$ $\nu(\mathrm{dppm}) 1105,755,690,555,505 ;{ }^{31} \mathrm{P}\left\{{ }^{1} \mathrm{H}\right\} \mathrm{NMR}, \mathrm{ppm}$, 36.23; ${ }^{1} \mathrm{H}$ NMR, ppm, 8.2(d, H(7,11), $\left.J=4 \mathrm{~Hz}\right), 8.12(\mathrm{~d}$, $\mathrm{H}(8,10), J=6.5 \mathrm{~Hz}), 1.9\left(\mathrm{~s}, \mathrm{~N}-\left(\mathrm{CH}_{3}\right),\right), 7.26(\mathrm{~d}, \mathrm{H}(4)$, $J=6 \mathrm{~Hz}), 7.34(\mathrm{~d}, \mathrm{H}(5), J=5 \mathrm{~Hz}), 7.1-7.2(\mathrm{~m}, \mathrm{dppm})$;
${ }^{19} \mathrm{~F} \quad\left\{{ }^{1} \mathrm{H}\right\} \mathrm{NMR}, \quad$ ppm, $\quad-78.02(\mathrm{OTf}), \quad{ }^{13} \mathrm{C} \quad\left\{{ }^{1} \mathrm{H}\right\} \mathrm{NMR}$, ppm, 129, 129.3-130.4(dppm, 18C), 134.5(C2), 124(C4), 125(C5), 125.3(C7,11), 129(C8,10), 134(C6), not obs.(Me Gr.); ESIMS, $801(\mathrm{M}-\mathrm{OTf})$; Analysis for $\left[\mathrm{Au}^{\mathrm{III}}(\mathrm{dppm})\right.$ (HaaiEt) $](\mathrm{OTf})_{2}$, 2a, Found, C, 55.3, H, 4.46, N, 7.26, Calcd. For $\left[\mathrm{C}_{36} \mathrm{H}_{34} \mathrm{~N}_{4} \mathrm{P}_{2} \mathrm{Au}\right]\left(\mathrm{OSO}_{2} \mathrm{CF}_{3}\right)_{2}, \mathrm{C}, 55.38, \mathrm{H}, 4.2$, $\mathrm{N}, 7.24$; IR $v(\mathrm{~N}=\mathrm{N}) 1370 v(\mathrm{C}=\mathrm{N}) 1590 \nu(\mathrm{dppm})$ 1100,750, 690,555,505; ${ }^{31} \mathrm{P}\left\{{ }^{1} \mathrm{H}\right\} \mathrm{NMR}, \mathrm{ppm}, 36.33 ;{ }^{1} \mathrm{H}$ NMR, ppm, $8.12(\mathrm{~d}, \mathrm{H}(7,11), J=8 \mathrm{~Hz}), 8.02(\mathrm{~d}, \mathrm{H}(8,10), J=6.5 \mathrm{~Hz})$, $7.26(\mathrm{~d}, \mathrm{H}(4), J=6 \mathrm{~Hz}), 7.3(\mathrm{~d}, \mathrm{H}(5), J=4 \mathrm{~Hz}), 4,1.88(\mathrm{~N}-$ Et), 7.01-7.2(m, dppm); ${ }^{19} \mathrm{~F}\left\{{ }^{1} \mathrm{H}\right\} \mathrm{NMR}, \mathrm{ppm},-78.02$ (OTf), ${ }^{13} \mathrm{C} \quad\left\{{ }^{1} \mathrm{H}\right\} \mathrm{NMR}, \quad$ ppm, 129.1, $129.3-130(\mathrm{dppm}, 18 \mathrm{C})$, 134.5(C2), 124(C4), 125(C5), 125.3(C7,11), 129.2(C8,10), 134(C6), not obs. (Et Gr.); ESIMS, 781(M-OTf); Analysis for $\left[\mathrm{Au}^{\mathrm{III}}(\mathrm{dppm})(\right.$ MeaaiEt $\left.)\right](\mathrm{OTf})_{2}, \mathbf{2 b}$, Found, C, 55.83, $\mathrm{H}, 4.56, \mathrm{~N}, 7.06$, Calcd. For $\left[\mathrm{C}_{37} \mathrm{H}_{36} \mathrm{~N}_{4} \mathrm{P}_{2} \mathrm{Au}\right]\left(\mathrm{OSO}_{2} \mathrm{CF}_{3}\right)_{2}$, C, 55.8, H, 4.52, N, 7.04; IR $v(\mathrm{~N}=\mathrm{N}) 1370 \quad v(\mathrm{C}=\mathrm{N})$ $1590 v(\mathrm{dppm}) 1100,750,690,550,505 ;{ }^{31} \mathrm{P}\left\{{ }^{1} \mathrm{H}\right\} \mathrm{NMR}$, ppm, 36.03; ${ }^{1} \mathrm{H}$ NMR, ppm, 8.0(d, H(7,11), $\left.J=8 \mathrm{~Hz}\right)$, $8.02(\mathrm{~d}, \mathrm{H}(8,10), J=6.5 \mathrm{~Hz}), 1.9\left(\mathrm{~s}, \mathrm{H}\left(\mathrm{CH}_{3}\right), 4.0,2.0(\mathrm{~N}-\right.$ Et), $7.26(\mathrm{~d}, \mathrm{H}(4), J=6 \mathrm{~Hz}), 7.34(\mathrm{~d}, \mathrm{H}(5), J=5 \mathrm{~Hz})$, 7.1-7.2(m, dppm); ${ }^{19} \mathrm{~F} \quad\left\{{ }^{1} \mathrm{H}\right\} \mathrm{NMR}, \quad$ ppm, -78.02(OTf), ${ }^{13} \mathrm{C} \quad\left\{{ }^{1} \mathrm{H}\right\} \mathrm{NMR}, \quad$ ppm, 129.1, $129-130.4(\mathrm{dppm}, 18 \mathrm{C})$, 
134.5(C2), 124(C4), 125(C5), 125.3(C7,11), 129.2(C8,10), 134(C6), 30,42(Et Gr.); ESIMS, 795(M-OTf); Analysis for $\left[\mathrm{Au}^{\mathrm{III}}(\mathrm{dppm})(\mathrm{ClaaiEt})\right](\mathrm{OTf})_{2}$, 2c, Found, C, 51.53, H, 4.06, N, 6.86, Calcd. For $\left[\mathrm{C}_{36} \mathrm{H}_{33} \mathrm{~N}_{4} \mathrm{P}_{2} \mathrm{AuCl}\right]\left(\mathrm{OSO}_{2} \mathrm{CF}_{3}\right)_{2}$, C, 51.58, H, 4.02, N, 6.84; IR $v(\mathrm{~N}=\mathrm{N}) 1370 \nu(\mathrm{C}=\mathrm{N}) 1590$ $v(\mathrm{dppm}) 1105,755,695,555,505 ;{ }^{31} \mathrm{P}\left\{{ }^{1} \mathrm{H}\right\} \mathrm{NMR}, \mathrm{ppm}$, 36.13; ${ }^{1} \mathrm{H}$ NMR, ppm, 8.2(d, H(7,11), $\left.J=8 \mathrm{~Hz}\right), 8.02(\mathrm{~d}$, $\mathrm{H}(8,10), J=6.5 \mathrm{~Hz}), 4.0,1.9(\mathrm{~s}, \mathrm{~N}-(\mathrm{Et})),, 7.26(\mathrm{~d}, \mathrm{H}(4)$, $J=6 \mathrm{~Hz}), 7.34(\mathrm{~d}, \mathrm{H}(5), J=5 \mathrm{~Hz}), 7.1-7.2(\mathrm{~m}, \mathrm{dppm}) ;{ }^{19} \mathrm{~F}$ $\left\{{ }^{1} \mathrm{H}\right\} \mathrm{NMR}, \mathrm{ppm},-78.02$ (OTf), ${ }^{13} \mathrm{C}\left\{{ }^{1} \mathrm{H}\right\} \mathrm{NMR}, \mathrm{ppm}, 129.1$, 129.3-130.4(dppm, 18C), 134(C2), 124(C4), 125(C5), 125.3(C7,11), 129.2(C8,10), 134(C6), 30, 42(Et Gr.); ESIMS, 815(M-OTf); Analysis for $\left[\mathrm{Au}^{\mathrm{III}}(\mathrm{dppm})(\mathrm{HaaiBz})\right](\mathrm{OTf})_{2}$, 3a, Found, C, 58.33, H, 4.26, N, 6.6, Calcd. For $\left[\mathrm{C}_{41} \mathrm{H}_{36} \mathrm{~N}_{4} \mathrm{P}_{2} \mathrm{Au}\right]\left(\mathrm{OSO}_{2} \mathrm{CF}_{3}\right)_{2}, \mathrm{C}, 58.8, \mathrm{H}, 4.2, \mathrm{~N}, 6.4$; IR $v(\mathrm{~N}=\mathrm{N}) 1370 v(\mathrm{C}=\mathrm{N}) 1590 v(\mathrm{dppm}) 1100,750,690$, 550, 505; ${ }^{31} \mathrm{P}\left\{{ }^{1} \mathrm{H}\right\}$ NMR, ppm, 36.13; ${ }^{1} \mathrm{H}$ NMR, ppm, 8.2(d, $\mathrm{H}(7,11), J=8 \mathrm{~Hz}), 8.02(\mathrm{~d}, \mathrm{H}(8,10), J=6.5 \mathrm{~Hz}), 5.29(\mathrm{~s}$, $\mathrm{N}(\mathrm{Bz}), 7.26(\mathrm{~d}, \mathrm{H}(4), J=6 \mathrm{~Hz}), 7.34(\mathrm{~d}, \mathrm{H}(5), J=5 \mathrm{~Hz})$, 7.1-7.2(m, dppm); ${ }^{19} \mathrm{~F} \quad\left\{{ }^{1} \mathrm{H}\right\} \mathrm{NMR}, \mathrm{ppm},-78.02$ (OTf), ${ }^{13} \mathrm{C} \quad\left\{{ }^{1} \mathrm{H}\right\} \mathrm{NMR}$, ppm, 129.1, $129.3-130.4(\mathrm{dppm}, 18 \mathrm{C})$, 134.5(C2), 124(C4), 125(C5), 125.3(C7,11), 129.2(C8,10), 134(C6), 42(Me Gr.); ESIMS, 843(M-OTf); Analysis for $\left[\mathrm{Au}^{\mathrm{III}}(\mathrm{dppm})(\mathrm{MeaaiBz})\right](\mathrm{OTf})_{2}, 3 \mathbf{b}$, Found, C, 58.83, H, 4.46, $\mathrm{N}, 6.36$, Calcd. For $\left[\mathrm{C}_{42} \mathrm{H}_{38} \mathrm{~N}_{4} \mathrm{P}_{2} \mathrm{Au}\right]\left(\mathrm{OSO}_{2} \mathrm{CF}_{3}\right)_{2}$, C, 58.8, H, 4.42, N, 6.4; IR $\nu(\mathrm{N}=\mathrm{N}) 1370 \nu(\mathrm{C}=\mathrm{N}) 1590$ $\nu(\mathrm{dppm}) 1100,750,690,550,505 ;{ }^{31} \mathrm{P}\left\{{ }^{1} \mathrm{H}\right\} \mathrm{NMR}, \mathrm{ppm}$, 36.3; ${ }^{1} \mathrm{H}$ NMR, ppm, 8.2(d, $\left.\mathrm{H}(7,11), J=8 \mathrm{~Hz}\right), 8.12(\mathrm{~d}$, $\mathrm{H}(8,10), J=6.5 \mathrm{~Hz}), 1.9\left(\mathrm{~s}, \mathrm{H}\left(\mathrm{CH}_{3}\right),\right), 7.26(\mathrm{~d}, \mathrm{H}(4)$, $J=6 \mathrm{~Hz}), 7.34(\mathrm{~d}, \mathrm{H}(5), J=5 \mathrm{~Hz}), 7.1-7.2(\mathrm{~m}, \mathrm{dppm})$; ${ }^{19} \mathrm{~F}\left\{{ }^{1} \mathrm{H}\right\} \mathrm{NMR}, \mathrm{ppm},-78.02$ (OTf), ${ }^{13} \mathrm{C}\left\{{ }^{1} \mathrm{H}\right\} \mathrm{NMR}$, ppm, 129.1, 129.3-130.4(dppm, 18C), 134.5(C2), 124(C4), 125(C5), 125.3(C7,11), 129.2(C8,10), 134(C6), ESIMS, 857(M-OTf); Analysis for $\left[\mathrm{Au}^{\mathrm{III}}(\mathrm{dppm})(\mathrm{ClaaiBz})\right](\mathrm{OTf})_{2}$, 1a, Found, C, 56.83, H, 4.06, N, 6.36, Calcd. For $\left[\mathrm{C}_{41} \mathrm{H}_{35} \mathrm{~N}_{4} \mathrm{P}_{2} \mathrm{AuCl}\right]\left(\mathrm{OSO}_{2} \mathrm{CF}_{3}\right)_{2}, \mathrm{C}, 56.8, \mathrm{H}, 4.02, \mathrm{~N}$, 6.4; IR $v(\mathrm{~N}=\mathrm{N}) 1370 \nu(\mathrm{C}=\mathrm{N}) 1595 v(\mathrm{dppm})$ 1105, 750, 695, 555, 505; ${ }^{31} \mathrm{P}\left\{{ }^{1} \mathrm{H}\right\} \mathrm{NMR}, \mathrm{ppm}, 36.3 ;{ }^{1} \mathrm{H}$ NMR, ppm, 8.2(d, $\mathrm{H}(7,11), J=8 \mathrm{~Hz}), 8.02(\mathrm{~d}, \mathrm{H}(8,10), J=6.5 \mathrm{~Hz}), 4.9(\mathrm{~s}$, $\mathrm{H}(\mathrm{Bz}), 7.26(\mathrm{~d}, \mathrm{H}(4), J=6 \mathrm{~Hz}), 7.34(\mathrm{~d}, \mathrm{H}(5), J=5 \mathrm{~Hz})$, 7.1-7.2(m, dppm); ${ }^{19} \mathrm{~F}\left\{{ }^{1} \mathrm{H}\right\} \mathrm{NMR}, \mathrm{ppm},-78.02(\mathrm{OTf})$, ${ }^{13} \mathrm{C} \quad\left\{{ }^{1} \mathrm{H}\right\} \mathrm{NMR}, \quad p p m, 129.1,129.3-130.4(\mathrm{dppm}, 18 \mathrm{C})$, 134.5(C2), 124(C4), 125(C5), 125.3(C7,11), 129.2(C8,10), 134(C6), ESIMS, 877(M-OTf).

\section{Acknowledgment}

The Ministerio De Education Y Ciencia (Grant no. SB20040060), Madrid, is thanked for financial support.

\section{References}

[1] C. M. Che, H. L. Kwong, W. W. Yam, T. F. Lai, and C. M. Che, "A novel series of gold(III)-bis-triphenylphosphinearylazoimidazole complexes: synthesis and spectroscopic and redox study," Journal of the Chemical Society, Dalton Transactions, p. 3747, 1990.
[2] H. Schmidbaur, Ed., Gold: Progress in Chemistry, Biochemistry and Technology, John Wiley \& Sons, Chichester, UK, 1999.

[3] A. J. Lewis, J. Cottney, D. D. White, et al., "Action of gold salts in some inflammatory and immunological models," Agents and Actions, vol. 10, no. 1-2, pp. 63-77, 1980.

[4] C. K. Mirabelli, C.-M. Sung, J. P. Zimmerman, D. T. Hill, S. Mong, and S. T. Crooke, "Interactions of gold coordination complexes with DNA," Biochemical Pharmacology, vol. 35, no. 9, pp. 1427-1433, 1986.

[5] C. K. Mirabelli, R. K. Johnson, C. M. Sung, L. Faucette, K. Muirhead, and S. T. Crooke, "Evaluation of the in vivo antitumor activity and in vitro cytotoxic properties of auranofin, a coordinated gold compound, in murine tumor models," Cancer Research, vol. 45, no. 1, pp. 32-39, 1985.

[6] P. Byabartta, "A novel series of sulphur-bridged rutheniummolybdenum complexes: [( $\left.\left.\operatorname{RaaiR}^{\prime}\right)_{2} \mathrm{Ru}(\mu-\mathrm{S})_{2} \mathrm{Mo}(\mathrm{OH})_{2}\right]$. Synthesis, spectroscopic and electrochemical characterization. RaaiR' $^{\prime}$ 1-alkyl-2-(arylazo) imidazole," Transition Metal Chemistry, vol. 30, no. 5, pp. 575-581, 2005.

[7] P. Byabartta, "Synthesis, spectra and electrochemistry of dinitro-bis-\{1-alkyl-2-(arylazo) imidazole $\}$ ruthenium(II). Nitro-nitroso derivatives and reactivity of the electrophilic $\{\mathrm{Ru}-\mathrm{NO}\}^{6}$ system," Transition Metal Chemistry, vol. 30, no. 7, pp. 804-813, 2005. 